\title{
Effects of Plant Lectins on in vitro Fibroblast Proliferation
}

\author{
Ana Maria Sell ${ }^{1 *}$ and Celso Paulino da Costa ${ }^{2}$ \\ ${ }^{l}$ Departamento de Análises Clínicas; Universidade Estadual de Maringá; Av. Colombo, 5790; 87.020-900; \\ Maringá - PR - Brazil. ${ }^{2}$ Departamento de Diagnóstico Oral; FOP; UNICAMP; Av. Limeira, s/n; Piracicaba - SP - \\ Brazil
}

\begin{abstract}
Lectins are carbohydrate-binding proteins that have been isolated from various sources and presented a wide spectrum of biological activities. The effects of four lectins, namely, Phaseolus vulgaris phytohemagglutinin, PHA, wheat germ agglutinin, WGA, Artocarpus integrifolia seed lectins, jacalin and artocarpin, on in vitro fibroblasts proliferation were investigated. The lectins did not influence the initial cell adhesion to the plate. PHA and WGA at 10-20 $\mu \mathrm{g} / \mathrm{mL}$ concentrations significantly decreased fibroblasts proliferation. At these concentrations, they caused morphological alterations on cells and over $80 \mu \mathrm{g} / \mathrm{mL}$, promoted cell death. Neither jacalin nor artocarpin significantly affected cell proliferation.
\end{abstract}

Key words: Lectins, fibroblasts, proliferation, MTT

\section{INTRODUCTION}

Lectins are structurally diverse carbohydratebinding proteins of non-immune origin that have been isolated from various sources such as bacteria, plants and animals (Sharon and Lis, 1989). They have been used to study the role of multivalent ligands to plasma membrane in the induction of specific biological responses. These multivalent molecules can cross-link a variety of cell surface receptors and produce a wide spectrum of biological activities such as stimulatory or inhibitory effects (Poretz et al., 1980; Kaplowitz, 1985; Kulkarne and McCulloch, 1995; Dean et al., 1999).

Several authors have studied the effects of various lectins on human fibroblasts with or without purified growth factors. Certain lectins noncompetitively inhibit the response of multiple peptides mitogens on in vitro cellular proliferation
(Kaplowitz, 1985). In other instances, internalization of the ligand and massive accumulation of vacuoles in murine fibroblasts have been reported (Poretz et al., 1980). Some lectins inhibit the spread of fibroblasts on collagen fibrils and the fibroblast-mediated collagen gel contraction by their binding to collagen receptor on the cell membrane (Asaga and Yoshizato, 1992). They also inhibit fibroblast attachment, spreading and migration on laminin substrates (Dean et al., 1999).

Direct effects of lectins on human fibroblasts proliferation have not been studied in details. The aim of this investigation was to determine the effect of the Phaseolus vulgaris phytohemagglutinin (PHA), wheat germ agglutinin (WGA) and Artocarpus integrifolia seeds lectins, jacalin and artocarpin, on in vitro fibroblast proliferation.

\footnotetext{
* Author for correspondence
} 


\section{MATERIALS AND METHODS}

Human gingival fibroblasts were obtained from healthy volunteer donors. Fibroblasts were grown and maintained in $15 \mathrm{~mL}$ or $50 \mathrm{~mL}$ plastic dishes in Dulbecco's Modified Eagles's Medium (DMEM - Sigma Chemical Co.) containing $23 \mathrm{mM}$ sodium bicarbonate, antibiotics and $10 \%(\mathrm{v} / \mathrm{v})$ fetal calf serum (Cutilab - Campinas), in a moisture atmosphere of $5 \% \mathrm{CO}_{2} / 95 \%$ air at $37^{\circ} \mathrm{C}$. Cells were detached from dishes with solution containing $0.1 \%$ trypsin and $1.0 \mathrm{mM}$ EDTA, collected by centrifugation and used after washing. Cells from passages 6 to 14 were used (Dohlman et al., 1985). Subculturing was done once or twice a week.

Lectins were Phaseolus vulgaris agglutinin, PHA, wheat germ agglutinin, WGA and Artocarpus integrifolia seeds lectins, jacalin and artocarpin. PHA and jacalin were prepared according to Gonçalves and Costa (1995) and Roque-Barreira et al. (1986). WGA was obtained from Sigma Chemical Co. Artocarpin, A. integrifolia seeds mannose specific lectin (Miranda-Santos et al., 1991), was purified from affinity chromatography on insoluble ovomucoid, according to Freier et al. (1985) and Gonçalves and Costa (1995). Lectins were dissolved in DMEM or PBS and used in final concentrations of $0.1 \mu \mathrm{g} / \mathrm{mL}$ to $300 \mu \mathrm{g} / \mathrm{mL}$, after sterilized in Amicon filter (0.22 mm - Millipore).

Fibroblasts were seeded on a 96 multiwell microtiter plate (Falcon 30075, Becton Dickson Labware) and cultivated in medium with lectins: during 24 hours for cytotoxicity assay; during 5 days for proliferation experiment; during 16 hours after adsorption of lectins in adhesion assays. Proliferation and adhesion assays have been previously described by Wieser and Oesch (1988) and Oppenheimer-Marks and Grinnel (1981), respectively. Toxicity assay was based on the method of Asaga and Yoshizato (1992). Results consisted of mean of three or four determinations and all analyses were made in triplicate.

Adhesion, cell growth and morphology of the fibroblasts were accompanied in phase contrast and inversion microscopy (Microscope ReichertJung, Biostar). Proliferation, adhesion and cytotoxicity were evaluated by MTT (Sigma Chemical Co.) colorimetric assay (Mosmann, 1983). Colored formazan products were measured at 490nm on the Microplate Reader (Biorad). This modification was due to conditions at our laboratory.

\section{RESULTS AND DISCUSSION}

Sensitivity and linearity of modified method: The colorimetric MTT method measured conversion of salt (3-(4,5-dimetylthiazol-2-yl)-2,5diphenyltetrazolium bromide) into intensely colored formazan products by mithocondrial enzymes. Rapidness, precision, lacks of any radioisotope (Mosmann, 1983) and same or higher sensitivity than ${ }^{3} \mathrm{H}$ - timidine incorporation assay (Dalmau et al., 1993; Gieni et al., 1995) are the advantages of the method.

In the original method, the colored product was read at 570nm (Mosmann, 1983) however we used $490 \mathrm{~nm}$.

Since the wavelength used in the experiments was different from that established by the original method, sensitivity and linearity were evaluated. Results are given in Fig.1.

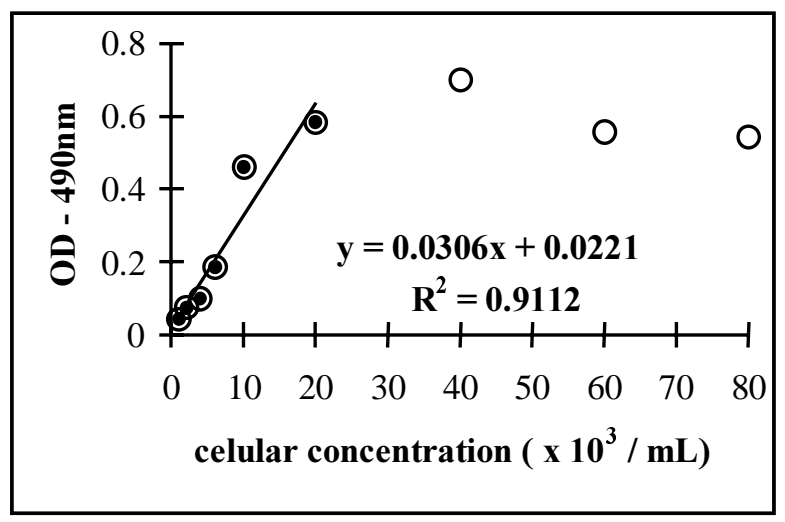

Figure 1 - Sensibility and linearity evaluation of colorimetric MTT modified method. The measures were done at $490 \mathrm{~nm}$. Linear model was adjusted for only six experimental points $(\odot)$.

Relationship between the readings of optical density (OD) at $490 \mathrm{~nm}$ and cell concentration (1.0 to $20 \times 10^{3}$ cells $/ \mathrm{mL}$ ) was appropriately described $\left(\mathrm{R}^{2}=0.91\right)$ for linear model. In the case of higher concentrations, the values of OD were not appropriated for this model. This fact could be associated to the inhibition of cell growth owing to cell-cell contact (Wieser and Oechi, 1988; Wieser et al., 1995). The linear model obtained was statistically significant at $1 \%$ level. The dependent 
variable (OD) was sensitive to the independent variable (cell concentration), a fact that confirmed the method's sensitivity. Since linearity and sensitivity were conserved, the method was used for measuring the fibroblast proliferation.

Cytotoxicity assay: The effect of lectins' toxicity on fibroblasts was analyzed. Viability of fibroblasts was measured by colorimetric MTT assay after being cultured for $24 \mathrm{~h}$ in the presence of PHA, WGA, jacalin and artocarpin. Although other necessary assays to confirm cytotoxicity, as neutral red uptake and bromodeoxyuridine and $3 \mathrm{H}$-thymidine incorporation were not tested, lectins did not seem to be cytotoxic. When the fibroblasts were cultivated in the medium with lectins ( 0.1 to $20 \mu \mathrm{g} / \mathrm{mL}$ ) during $24 \mathrm{~h}$, no change occurred in cell viability (Fig.2). Data are given as relative viability (the results of the controls were held to be $100 \%$ ).

Asaga and Yoshizato (1992) reported that PHA or WGA did not affect the viability of fibroblasts cultured on plain plastic at a concentration of 100 $\mu \mathrm{g} / \mathrm{mL}$.

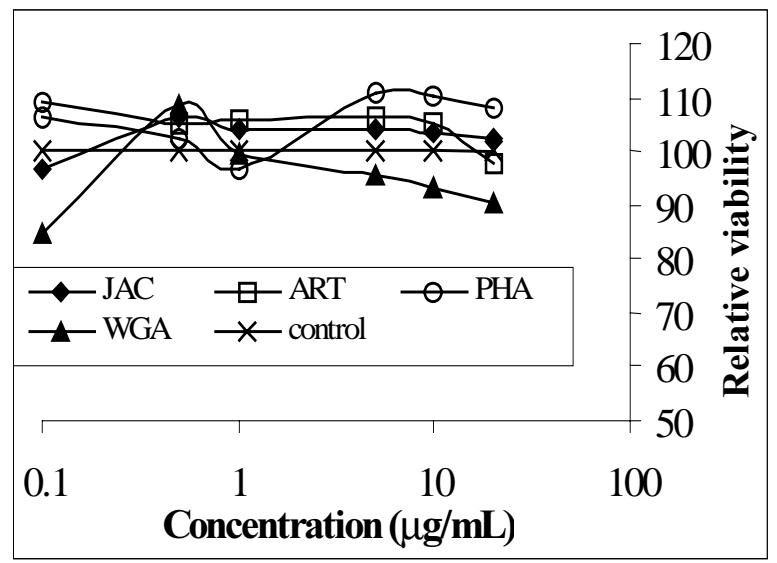

Figure 2 - Effect of PHA, WGA, jacalin and artocarpin on fibroblasts viability.

Cell adhesion assays: Fibroblast's initial adhesion on polystyrene micro titer plate after lectins-coated surface is shown in Fig.3. Fibroblast attached to lectins-coated plates as well as to control (PBS)coated plate. Fibroblast adhesion was not significantly modified by lectins ( 0.1 to 300 $\mu \mathrm{g} / \mathrm{mL}$ ). Data are given as relative adhesion, as long as results of the controls-coated plates were held to be $100 \%$.

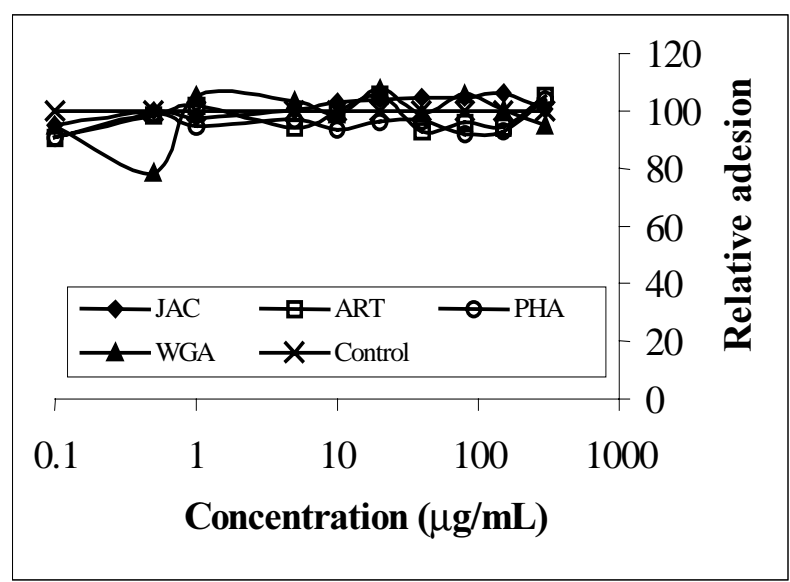

Figure 3 - Effect of PHA, WGA, jacalin and artocarpin lectins on fibroblasts adhesion on plastic plate.

Effects of lectins on fibroblast proliferation: Effects of PHA, WGA, jacalin and artocarpin lectins on fibroblasts proliferation were evaluated and results are given in Fig.4. OD differences in the medium values (controls minus treated) were statistically analyzed (Student's $t$ test). Full symbols meant significant differences at 5\% level for each lectin. Maximum positive differences represented $100 \%$ of cell mortality. PHA and WGA caused significant effect over $20 \mu \mathrm{g} / \mathrm{mL}$. Effect of jacalin was significant only at maximum concentration. Artocarpin didn't influence the proliferation.

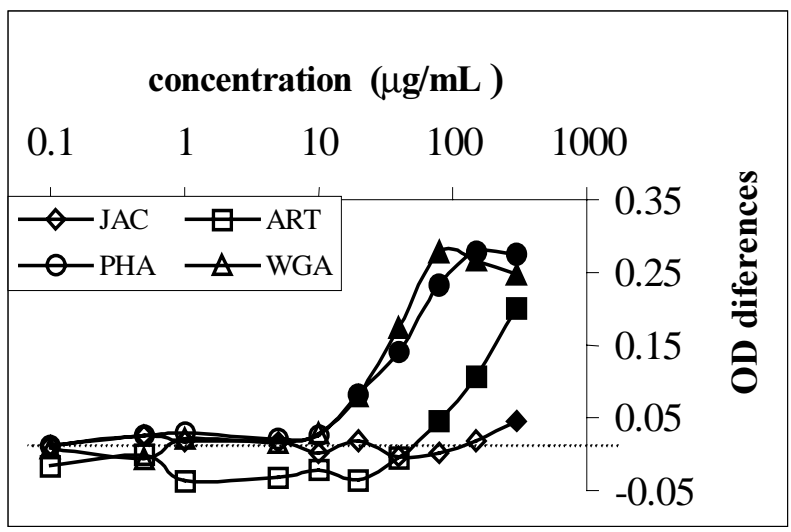

Figure 4 - Effect of PHA, WGA, jacalin and artocarpin on fibroblasts proliferation rate. Full symbols indicate significant differences at $5 \%$. 
Cell surface carbohydrates play important regulatory roles mediating cellular signaling. Plant lectins cross-link to specific carbohydrates residues on cell surface glycoproteins and may mimic the mitogen action (Kaplowitz, 1985; Kulkarne and McCulloch, 1995). When exposed to lectin Wistaria floribunda agglutinin (WFA) cultured BALB/c 3T3 fibroblasts became highly vacuolated, however, cell growth, division or metabolism remained unaltered. Other lectins tested did not cause lysosome accumulation (Poretz et al., 1980).

Carpenter and Stanley (1977), Kaplowitz (1985) and Kaplowitz and Haar (1988) tested the ability of lectins to provoke a cell response that has normally been generated by the interaction of epidermal growth factor (EGF) with human fibroblasts. WGA and concanavalin A (Con A) had little effect on 3H-dT incorporation in cultures of quiescent and confluent fibroblast. Both inhibited the EGF and insulin-stimulated DNA synthesis. PHA inhibited EGF-stimulated DNA synthesis but actually increased surface binding by $75 \%$. The incubation of fibroblast with PHA and WGA decreased cell spreading. However, other lectins failed to inhibit EGF-stimulated DNA synthesis and did not modify cell morphology. Wieser and Oesch (1988) cultured diploid human fibroblasts in the presence of specific lectins for terminal galactose residues. They reported that the addition of lectins from Bandeiraea simplicifolia (BSI) resulted in a lectin concentration-dependent increase in the proliferation rate. The Ulex europeus lectins had no effect on proliferation, whereas Con A and WGA strongly inhibited the growth rate. These results showed that the presence of galactose residue terminal on plasmatic membrane was vital for the efficient growth control of normal cells. BSI linked to galactose residues inactivated the contact inhibition (Wieser, Baumann and Oesch, 1995).

Asaga and Yoshizato (1992) cultured fibroblast in collagen gels in the presence of several lectins at various concentrations $(10,20$ or $50 \mu \mathrm{g} / \mathrm{mL})$. PHA, WGA, Con A, among others, inhibited fibroblast mediated collagen contraction in a concentration dependent manner. Results suggested that PHA and WGA recognized the glycochain of collagen receptor at cell surface. Receptor may belong to integrin family, particularly fibronectin. Kulkarne and McCulloch (1995) used Con A to examine the role of cell surface carbohydrates in apoptosis. Human gingival fibroblasts incubated with lectin exhibited ultra-structural changes consistent with apoptotic cell death. Con A binding of cell surface carbohydrates induced apoptosis through inhibition of protein synthesis. Dean et al. (1999) examined the effects of lectins on attachment, spreading and migration response of fibroblasts on in vitro glycosylated laminin. WGA inhibited fibroblast binding to laminin, Con A inhibited cell spreading and both inhibited migration of fibroblasts. Biotin-labeled WGA detected pattern binding on fibroblast confluent monolayer. WGA bind to the cell's surface structure and predominantly to extracellular fibers (Nizheradze, 2000). Moore et al. (2000) identified a new lectin in red-kidney beans called PvFRIL that specifically stimulated proliferation of NIH 3T3 fibroblasts. Effect of several lectins in wound healing of rats' skin showed that PHA enhanced, WGA decreased and jacalin did not influence the cicatricial process (Sell and Costa, 1998). To evaluate whether this effect was related directly to lectins-stimulated fibroblast, effect of lectins on fibroblast proliferation was studied in vitro.

The present study demonstrated that PHA and WGA lectins significantly inhibited fibroblast proliferation (Fig 4). Only PHA concentration of 0.1 to $10 \mu \mathrm{g} / \mathrm{mL}$ failed to influence cell proliferation. However, WGA decreased cell proliferation from $10 \mu \mathrm{g} / \mathrm{mL}$. When WGA concentration was $40 \mu \mathrm{g} / \mathrm{mL}$, proliferation was almost stopped.

Changes in fibroblasts shapes occurred when PHA and WGA were used from $20 \mu \mathrm{g} / \mathrm{mL}$. Most fibroblast remained round in shape, cell spreading was inhibited and cells could be removed when the medium was replaced. Cell death was $100 \%$ at the highest concentration (150 and $300 \mu \mathrm{g} / \mathrm{mL})$. Changes in cell shape would be responsible for inhibitory effects: they may alter the interaction between mitogen receptors and cytoplasm components needed for transmembrane signaling and modify spreading which is important in cell proliferation.

Jacalin didn't modify fibroblast's morphology, initial adhesion or proliferation rate. According to Wieser and Oesch (1988), diploid human fibroblasts, cultured in the presence of terminal galactose residues for specific lectins, increased proliferation rate. In our research jacalin, specific for galactose residues lectin, failed to increase the proliferation rate. This effect could be correlated with different linked lectin-receptor and 
consequently different biological effects. Besides, jacalin can bind to specific glycoproteins of the serum (Costa, 1989; Dalmau et al., 1989). It could thus be suggested that when fibroblasts were cultivated in the medium supplement with fetal calf serum, the lectin would bind to growth factors; therefore neither lectins nor growth factors were free to act as mitogenic ones.

Artocarpin slowly increased the fibroblast proliferation rate at concentrations between 1.0 and $20 \mu \mathrm{g} / \mathrm{mL}$. Although insignificant, we observed an increase in cell growth by inversion microscopy. From $48 \mathrm{~h}$ and at an $80 \mu \mathrm{g} / \mathrm{mL}$ concentration, artocarpin induced modification of cell morphology and cell death proportionally with time and lectin concentration. Artocarpin did not influence adhesion to polystyrene plate.

Lectin Con A interacted with mannose residues as artocarpin. Con A did not increase DNA synthesis (Carpenter and Cohen, 1977). Rather, it inhibited fibroblasts proliferation rate at high cell densities (Wieser and Oesch, 1988) and cell spreading (Dean et al., 1999) and, when incubated $(50 \mu \mathrm{g} / \mathrm{mL})$ with diploid human fibroblasts, exhibited round shape, size reduction and ultra structural changes, consistent with apoptotic cell death (Kulkarne and McCulloch, 1995). No PHA, WGA, jacalin and artocarpin lectins were mitogenic for fibroblasts.

\section{ACKNOWLEDGEMENTS}

We would like to thank Prof. Dr. Ricardo Della Colleta, Pathology Laboratory of FOP, Unicamp, Campinas SP Brazil; Prof. Dr. Antônio Carlos Andrade Gonçalves, Agronomy Department, UEM, Maringá PR Brazil and the support by CAPES/CNPq/FOP/UEM.

\section{RESUMO}

O objetivo deste trabalho foi avaliar a influência das lectinas PHA, WGA, jacalina e artocarpina sobre a proliferação de fibroblastos in vitro. Para tanto, fibroblastos gengivais de voluntários saudáveis foram cultivados, por cinco dias, em DMEM suplementado com soro bovino fetal $(10 \%$ $\mathrm{v} / \mathrm{v})$ e na presença das lectinas nas concentrações finais de 0.1 a $300 \mu \mathrm{g} / \mathrm{mL}$. A adesão, o crescimento e a morfologia celular foram acompanhados por microscopia de inversão e contraste de fase. $O$ índice de proliferação foi avaliado pelo método calorimétrico usando MTT. As lectinas não alteraram a adesão inicial dos fibroblastos à placa de poliestireno. PHA e WGA, nas concentrações de 10 a $20 \mu \mathrm{g} / \mathrm{mL}$, diminuíram significativamente a proliferação celular. Nestas concentrações a morfologia celular é alterada e acima de $80 \mu \mathrm{g} / \mathrm{mL}$, houve $100 \%$ de morte celular. As lectinas jacalina e artocarpina não influenciaram a proliferação celular.

\section{REFERENCES}

Asaga, H. and Yoshizato, K. (1992), Recognition of collagen by fibroblasts through cell surface glycoproteins reactive with Phaseolus vulgaris agglutinin. J. Cell Sci., 101, 625-633.

Carpenter, G. and Cohen, S. (1977), Influence of lectins on the binding of ${ }^{125} \mathrm{I}$ - labeled EGF to human fibroblasts. Biochem. Biophys. Res. Comm., 79 : (2), 545-552.

Costa, C. P. (1989), Interações de lectinas de semente de jaca (Artocarpus integrifolia) com glicoproteinas da saliva e do soro humano. PhD Thesis, Faculdade de Odontologia de Piracicaba, UNICAMP, Piracicaba, São Paulo, Brasil.

Dalmau, S. R.; Maciel, C. M. and Freitas, C. S. (1989), Jacalin: an excellent lectin for obtaining $\mathrm{T}$ cell growth activity from rat spleen cells. Braz. J. med. Res., 22, 1111-1120.

Dalmau, S. R.; Freitas, C. S. and Savino, W. A. (1993), Modified assay for measuring thymocyte co-stimulatory activity. Mem. Inst. Oswaldo Cruz, 88 : (3), 419-425.

Dean, J. W.; Karsen, B. and Briggett. P. (1999), Lectin inhibited periodontal ligament fibroblast attachment, spreading and migration on laminin substrates. $J$. Periodontal Res., 34 : (1), 41-49.

Dohlman, J. G.; Cooke, V. M. P.; Payan D. G. and Goetzl E. J. (1985), Structural diversity of the fibroblast-activating factors generated by human blood monocytes and U937 cells. J. Immunol., 134 : (5), 3185-3200.

Freier, T.; Fleischmann, G. and Rudiger, H. (1985), Affinity chromatography on immobilized hog gastrin mucin and ovomucoid. A general method for isolation of lectins. Biol. Chem., 366, 1023-1028.

Gieni, S. R.; Li, Y. and Hayglass, K. T. (1995), Comparison of $[3 \mathrm{H}]$ thymidine incorporation with MTT- and MTS- based bioassays for human and murine $\mathrm{IL}^{-2}$ and $\mathrm{IL}^{-4}$ analysis: Tetrazolium assays provide markedly enhanced sensivity. J. Immunol. Methods, 187, 85-93. 
Gonçalves, R. B. and Costa, C. P. (1995), Isolation of the lectin and $\mathrm{L}_{4}$ isolectin from Phaseolus vulgaris by affinity chromatography on insoluble ovomucoid. Braz. J. med. Biol. Res., 28, 191-194.

Kaplowitz, P. B. (1985), Wheat germ agglutinin and concanavalin A inhibit the response of human fibroblasts to peptide growth factors by a postreceptor mechanism. J. Cell. Physiol., 124, 474-480.

Kaplowitz, P. B and Haar, J. L. (1988), Antimitogenic actions of lectins in cultured human fibroblasts. $J$. Cell. Physiol., 136, 13-22.

Kulkarni, G. V. and Mcculloch, C. A. (1995), Concanavalin A induced apoptosis in fibroblasts: the role of cell surface carbohydrates in lectin mediates cytotoxicity. J. Cell Physiol., 165, 119-133.

Miranda-Santos, I. K. F.; Delgado, M.; Bonini, P. V.; Bunn-Moreno, M. M. and Campos-Neto, A. (1991), A crude extract of Artocarpus integrifolia contains two lectins with distinct biological activities. Immunol. Lett., 31, 65-72.

Moore, J. G.; Fuchs, C. A., Hata, Y. S.; Hicklin, D. J.; Colucci, G.; Chrispeels, M. J. and Feldman, M. (2000), A new lectin in red kidney beans called PvFRIL stimulates proliferation of NIH $3 \mathrm{~T} 3$ cells expressing the Flt3 receptor. Biochim. Biophys. Acta, 1475 : (3), 216-224.

Mosmann, T. (1983), Rapid colorimeric assay for cellular growth and survival: application to proliferation and cytotoxicity assays. J. Immunol. Methods, 65, 55-63.

Nizheradze, K. A. (2000), Binding of wheat germ agglutinin to extracellular network produced by cultures human fibroblasts. Folia Histochem. Cytobiol., 38 : (4), 167-73.

Oppenheimer-Marks, N. and Grinnell, F. (1981), Effects os plants lectins on the adhesive properties of baby hamster kidney cells. Eur. J. Cell Biol., 23, 286-294.
Poretz, R. D.; Triemer, A. C.; St. John, A. C.; Merion, M.; Kuchler, R. J.; Cryan, D.; Carter, J. H. and Bird, J. W. C. (1980), Lectin-induced accumulation of large lysossomes in cultured fibroblasts. Exp. Cell Res., 128, 133-142.

Roque-Barreira, M. C.; Greene, L. J. and Campos-Neto, A. (1986), Purification of jacalin on agarose-Dgalactose. Braz. J. med. Biol. Res., 19 : (4/5), 638A.

Sharon, N. and Lis, H. (1989), Lectins as cell recognition molecules. Science, 246, 227-234.

Sell, A. M. and Costa, C. P. (1998), PHA: a lectin that enhanced wound healing in the skin rats. Paper presented at International Meeting on Vaccines, 29 Nov - 03 Dec, Salvador, Brazil.

Wieser, R. J. and Oesch, F. (1988), Contact-dependent regulation of growth of diploid human fibroblasts is dependent upon the presence of terminal galactose residues on plasma membrane glycoproteins. Exp. Cell Res., 176, 80-86.

Wieser, R J.; Baumann C. E. and Oesch, F. (1995), Cell-contact mediated modulation of the sialylation of contactinhibin. Glycoconj. J., 12, 672-679.

Received: November 29, 2001; Revised: June 04, 2002; Accepted: November 25, 2002. 